\title{
Oxygenated Geosmins and Plant-like Eudesmanes from a Bacterial Mangrove Endophyte
}

\section{Ding, Ling; Hertweck, Christian}

Published in:

Journal of Natural Products

Link to article, DOI:

10.1021/acs.jnatprod.0c00304

Publication date:

2020

Document Version

Peer reviewed version

Link back to DTU Orbit

Citation (APA):

Ding, L., \& Hertweck, C. (2020). Oxygenated Geosmins and Plant-like Eudesmanes from a Bacterial Mangrove Endophyte. Journal of Natural Products, 83(7), 2207-2211. https://doi.org/10.1021/acs.jnatprod.0c00304

\section{General rights}

Copyright and moral rights for the publications made accessible in the public portal are retained by the authors and/or other copyright owners and it is a condition of accessing publications that users recognise and abide by the legal requirements associated with these rights.

- Users may download and print one copy of any publication from the public portal for the purpose of private study or research.

- You may not further distribute the material or use it for any profit-making activity or commercial gain

- You may freely distribute the URL identifying the publication in the public portal 


\section{Oxygenated Geosmins and Plant-Like Eudesmanes from a Bacterial Mangrove Endophyte}

$\operatorname{Ling}_{\text {Ding }}^{\dagger, \ddagger} * *$ and Christian Hertweck ${ }^{\dagger, \perp}$

${ }^{\dagger}$ Leibniz Institute for Natural Product Research and Infection Biology - Hans Knöll Institute (HKI), Beutenbergstr. 11a, 07745 Jena, Germany

${ }^{\ddagger}$ Department of Biotechnology and Biomedicine, Technical University of Denmark, Søltofts Plads, Building 221, 2800 Kgs. Lyngby, Denmark

${ }^{\perp}$ Faculty of Biological Sciences, Friedrich Schiller University Jena, 07737 Jena, Germany

* Tel: (+) 45-50333791. E-mail: lidi@dtu.dk 


\section{ABSTRACT}

Geosmin (1) is a microbial terpene metabolite that is responsible for the typical smell of soil and causes an off-odor of food and water. Eudesmane sesquiterpenes are commonly found in plant essential oils. Here we describe the discovery of four geosmin-type metabolites, 7R-hydroxygeosmin (2), 3-oxogeosmin (3), 2R-

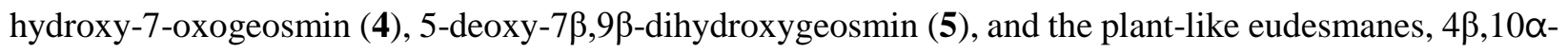
eudesmane-5 $\beta, 11$-diol (6) and (1S,5S,6S,7S,10S)-10 $\alpha$-eudesm-4(15)-ene-1 $\alpha, 6 \alpha$-diol (7), and the known 1(10)E,5E-germacradiene-2,11-diol (8), from a bacterial endophyte (Streptomyces sp. JMRC:ST027706) of the mangrove plant Bruguiera gymnorrhiza. By means of NMR, MS and ECD spectroscopy, all chemical structures as well as the absolute configurations for the new compounds were elucidated. Compounds $\mathbf{2 - 5}$ represent the first geosmin-related metabolites directly as bacterial natural products. The plant-derived eudesmane-5 $\beta, 11$-diol (6) and (1S,5S,6S,7S,10S)-10 $\alpha$-eudesm-4(15)-ene-1 $\alpha, 6 \alpha$-diol (7) were reported as bacterial products. The broad antimicrobial activities of $\mathbf{6}$ against a suite of fungal and bacterial pathogens including methicillin-resistant Staphylococcus aureus suggests that this terpene could be an important active principle of the medicinal plant Cymbopogon distans. The discovery of geosmin metabolites from one actinomycete indicated that these bacteria could possess enzymes for modifying geosmin and offer a possibility for bioremediation. 
Geosmin (1) is a terpene produced by a variety of microbes, mainly streptomycetes, cyanobacteria, myxobacteria, and fungi, that is responsible for the strong earthy-musty odor typical for freshly ploughed soil. Owing to its compact, 4,10-substituted decalin scaffold that lacks the typical isopropyl side chain of related eudesmane sesquiterpenoids, geosmin is highly volatile. ${ }^{1}$ Because animals and humans are capable of sensing geosmin at extremely low thresholds, various ecological roles have been implicated. ${ }^{2}$ For example, earthworms and springtails are attracted by geosmin as an indicator of humidity - and thus food source - and may in return play a role in the dispersal of streptomycetes spores. ${ }^{3}$ In contrast, geosmin detection by Drosophila flies helps them identifying unsuitable feeding and breeding sites. ${ }^{4}$ Generally, the ability of animals and humans to sense geosmin may raise the awareness of potentially dangerous microbes and thus helps to avoid rotten foods or contaminated water. ${ }^{5-6}$ Although geosmin does not exhibit any cytotoxicity in mammalian cell assays, ${ }^{7}$ it has received considerable attention due to its off-flavor in food and drinking water. ${ }^{8}$ Therefore, various avenues for geosmin degradation have been explored. ${ }^{9-10} \mathrm{~A}$ promising approach for bioremediation is the use of microbes that are able to modify geosmin. ${ }^{11-12}$ For example, two terpene-degrading bacteria, Pseudomonas sp. and Rhodococcus wratislaviensis, were reported to transform geosmin into its oxidation products, ketogeosmins and hydroxygeosmins. ${ }^{13}$ However, there is no report on geosmin degradation or transformation in typical geosmin producers such as actinomycetes, and naturally occurring geosmin derivatives are extremely scarce. Here we report the isolation, structure elucidation, and characterization of four oxygenated geosmin-type terpenes, along with two plant-like eudesmanes from a mangrove endophyte.

\section{Results and Discussion}

From the stem of the mangrove plant Bruguiera gymnorrhiza, we obtained the endophyte Streptomyces sp. JMRC:ST027706. ${ }^{14}$ Thin-layer chromatography (TLC) analysis of its extract showed typical blue to violet color reaction with anisaldehyde-sulfuric acid indicated the presence of bacterial terpenes. ${ }^{14}$ To elucidate the structures of these volatiles, the organic extract of a large scale fermentation broth ( $200 \mathrm{~L})$ was subjected 
to open-column chromatography on Amberchrom 161c resin, silica gel, and Sephadex LH-20, yielding compounds 2 (10.0 mg), 3 (2.2 mg), 4 (7.3 mg), 5 (2.1 mg), 6 (1.0 mg), 7 (2.1 mg), and 8 (0.6 mg), which were studied by NMR (Tables 1-2), MS and ECD spectroscopy. Due to the difficulties in ionization of compounds 2-5 using the electron spray ionization method, an electron ionization method was instead to be applied in providing informative data.

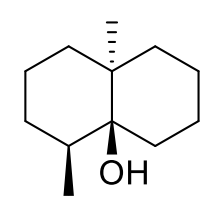

1

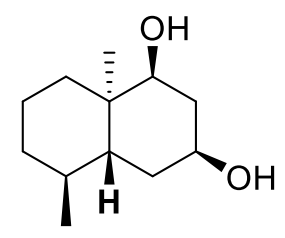

5

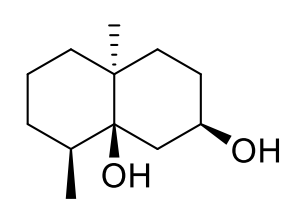

2

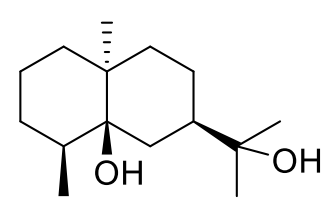

6

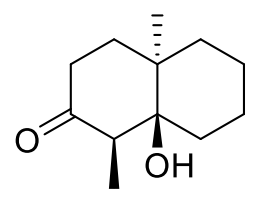

3

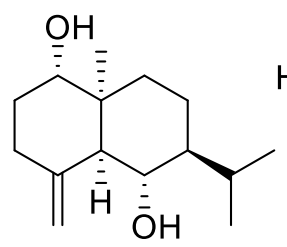

7

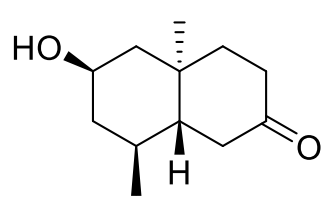

4

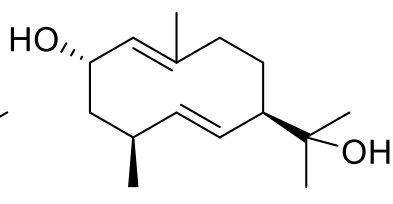

8

The ${ }^{1} \mathrm{H}$ NMR spectrum of compound 2 revealed the presence of one methyl singlet $(\delta 0.98, \mathrm{Me}-12)$, one methyl doublet $(\delta 0.80$, Me-11), three oxygen-bonding protons $(\delta 4.08, \mathrm{H}-7 ; \delta 3.55,7-\mathrm{OH} ; \delta 3.03,5-\mathrm{OH})$ as well as other aliphatic protons. ${ }^{13} \mathrm{C}$ NMR data indicated the presence of carbon signals constituting a decahydronaphthalene backbone, which was further corroborated by 2D NMR, especially by HMBC correlations (Figure 1). The relative configuration of $\mathbf{2}$ was deduced from the NOESY spectrum showing correlations between 5-OH (7-OH) and H-6 $\beta$, Me-12 and $\mathrm{H}-6 \alpha$, and Me-11 and 5-OH (Figure 1). Thus, the structure of $\mathbf{2}$ was established as $7 \beta$-hydroxygeosmin. Notably, a compound with the same structure has been reported as a synthetic product. ${ }^{15}$ Yet, the NMR spectra of the natural product and the synthetic compound differ in the coupling constant of H-7 with neighboring protons (synthetic, $J_{\mathrm{HH}}=10 \mathrm{~Hz}$; natural, broad singlet). 3D modeling (Figure S6) confirmed the small coupling constant for H-7 in the proposed structure of $\mathbf{2}$. The synthetic compound may be a diastereoisomer, with the hydroxy group in an equatorial position (Figure S6). 
Compound 3 was identified as another geosmin congener. The ${ }^{13} \mathrm{C}$ NMR spectrum showed 12 carbon signals, including a signal for one carbonyl group ( $\delta 212.0, \mathrm{C}-3)$ and one for an oxygen-bonding carbon $(\delta$ 78.7, C-5). We concluded that $\mathbf{3}$ is a geosmin derivative with a carbonyl group located at C-3 position. Its structure was proposed to be 3-oxo-geosmin. Correlations between H-4 and Me-12 in the NOESY spectrum established its relative configuration. The same compound has been reported as a geosmin biotransformation product by a Pseudomonas sp. that was investigated as a potential bioremediator strain. ${ }^{13}$ The ${ }^{13} \mathrm{C}$ NMR data of $\mathbf{3}$ are in agreement with the synthetic compound and confirms the relative configuration. ${ }^{16}$

The ${ }^{1} \mathrm{H}$ NMR spectrum of 4 indicated the presence of an oxygen-bonding methylene ( $\delta 4.18$, H-2), two methyls ( $\delta$ 0.82, Me-11, $\delta 1.27$, Me-12) as well as other aliphatic residues. In addition, the ${ }^{13} \mathrm{C}$ NMR spectrum showed a carbonyl signal ( $\delta 212.1, \mathrm{C}-7)$, which showed correlations with H-6, H-8 and H-9 in the HMBC spectrum (Figure 1). Together with COSY and HSQC correlations, compound $\mathbf{4}$ was established as $2 \beta$-hydroxy-7-oxogeosmin. Its relative configuration was established by correlations between $\mathrm{H}-5$ and Me-11, H-4 and Me-12, and H-2 and Me-12 in the NOESY spectrum (Figure 1). 2 $\beta$-Hydroxy-7oxogeosmin, represents a new natural product with a decalin scaffold.

In the ${ }^{1} \mathrm{H}$ NMR spectrum of $\mathbf{5}$, signals for two protons $(\delta 4.13, \mathrm{H}-7, \delta 3.31, \mathrm{H}-9)$ indicating it being an alcohol. Two methyl groups ( $\delta 0.83$, Me-11, $\delta 0.79$, Me-12) as well other aliphatic protons were observed. The location of two hydroxy groups at C-7 and C-9, was established by both COSY and HMBC correlations (Figure 1). The correlations between $\mathrm{H}-5$ and 7-OH, 7-OH and 9-OH, H-5 and Me-11, and Me-12 and H9 in the NOESY spectrum established its relative configuration (Figure 1). The new structure was established as 5-deoxy-7 $\beta, 9 \beta$-dihydroxygeosmin. 
Natural geosmin is typically found as the (-)-enantiomer, irrespective of the producing organism (prokaryotes or eukaryotes). ${ }^{8}$ To elucidate the absolute configuration of $\mathbf{3}$ and $\mathbf{4}$, we measured their ECD spectra and observed opposite Cotton effects between them (Figure S6-S7). According to the octant rule, we deduced the absolute configurations of all isolated geosmins and confirmed that they are related to the natural (-)-geosmin.

In addition to $\mathrm{C}_{12}$-decalins $\mathbf{2}-\mathbf{5}$ that are, like geosmin, derived from the truncation of a sesquiterpene precursor, we obtained congeners 6 and 7 as intact sesquiterpenes. The molecular formula of $\mathrm{C}_{15} \mathrm{H}_{28} \mathrm{O}_{2}$ was deduced for compound 6 by HRMS. The ${ }^{1} \mathrm{H}$ NMR spectrum showed signals of three methyl groups appearing as singlets $(\delta 1.24 \mathrm{Me}-12, \delta 1.24 \mathrm{Me}-13, \delta 1.03 \mathrm{Me}-14)$ and a signal of one methyl group appearing as a doublet $\left(\delta 0.83\right.$, Me-15). The ${ }^{13} \mathrm{C}$ NMR spectrum exhibited 15 signals, including two of oxygenated carbons resonating at $\delta 74.3$ (C-5) and $\delta 73.1$ (C-11). 2D NMR spectra, in particular COSY and $\mathrm{HMBC}$, revealed a eudesmane skeleton for compound $\mathbf{6}$. The locations of the two oxygenated carbons were deduced from HMBC correlations, where correlations between Me-12 (Me-13) and C-7 ( $\delta$ 40.8) and C-11 $(\delta 73.1)$, between Me-15 and C-5 ( $\delta 74.3)$ and C-10 ( $\delta$ 36.8), and between Me-15 and C-3 $(\delta 30.6)$ and C$5(\delta 74.3)$ were observed. Compound 6 represents $4 \beta, 10 \alpha$-eudesmane-5 $\beta, 11$-diol, which was reported as an essential oil component from the aromatic grass Cymbopogon distans. ${ }^{17}$ Its absolute configuration was confirmed by X-crystallography. ${ }^{17}$ Owing to the same specific rotation, both bacterial and plant eudesmane$5 \beta, 11$-diol share the same absolute configuration. Eudesmanes are relatively rare as bacterial products. Only

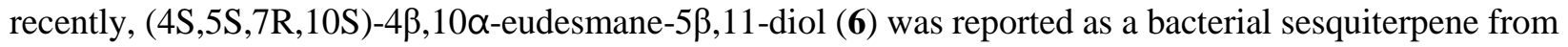
Streptomyces anulatus isolated from Giraffa camelopardalis. ${ }^{18}$

The ${ }^{1} \mathrm{H}$ NMR spectrum of 7 exhibits signals of an exo-methylene ( $\left.\delta 4.96, \delta 4.82, \mathrm{H}-15\right)$, two oxygenbonding methylenes $(\delta 3.92, \mathrm{H}-1, \delta 3.49, \mathrm{H}-6)$, three methyl groups $(\delta 0.82$, Me-12, $\delta 0.92, \mathrm{Me}-13, \delta 0.85$ Me-14), and other aliphatic residues. The ${ }^{13} \mathrm{C}$ NMR spectrum shows 15 carbons signals, including those for two olefinic $(\delta 145.4, \delta 114.2)$ and two oxygen-bonding carbons $(\delta 68.1, \delta 67.1)$. 2D NMR data (especially HMBC correlations) (Figure 1) corroborated the 4(15)-eudesmene-1,6-diol structure. The 2D NOESY 
spectrum established the relative configurations from correlations between $\mathrm{H}-1$ and H-6, H-5 and H-7/Me14, respectively. Compound 7 was elucidated as 4(15)-eudesmene- $1 \alpha, 6 \alpha$-diol. Interestingly, both enantiomers were reported from plants, such as Croton caudatus var. tomentosus, ${ }^{19}$ Guarea guidonia (Meliaceae), ${ }^{20}$ Caragana intermedi, ${ }^{21}$ Eupatorium fortune, ${ }^{22}$ and Litsea verticillata. ${ }^{23}$ Recently, (+)-10 $\alpha-$ eudesm-4(15)-ene-1 $\alpha, 6 \alpha$-diol was prepared in total synthesis. ${ }^{24-25}$ Based on the negative specific rotation, compound 7 was confirmed to be (1S,5S,6S,7S,10S)-10 $\alpha$-eudesm-4(15)-ene-1 $\alpha, 6 \alpha$-diol, which exhibited the opposite configuration with the synthetic one. This is the first report of (1S,5S,6S,7S, 10S)-10 $\alpha$-eudesm4(15)-ene-1 $\alpha, 6 \alpha$-diol as a bacterial metabolite.

Finally, we found that compound $\mathbf{8}$ is identical with 1(10)E,5E-germacradiene-2,11-diol, which was previously reported as a metabolite of an endophyte (Streptomyces griseus subsp.) isolated from the mangrove plant Kandelia candel. ${ }^{26}$

To test the antimicrobial activities of geosmins and other isolated terpenes, we performed agar diffusion assays against a suite of bacteria and fungi. Compounds $\mathbf{2}$ and $\mathbf{3}$ exhibited only weak antibacterial activities (Table 3). Thus, it is unlikely that those geosmin compounds act as antibiotics in nature. In stark contrast, we found that $\mathbf{6}$ exerts broad antimicrobial activities against all tested bacteria (Bacillus subtilis, Mycobacterium vaccae, Pseudomonas aeruginosa, Staphylococcus aureus, methicillin-resistant Staphylococcus aureus, vancomycin-resistant Enterococcus faecalis and Escherichia coli) and fungi (Sporobolomyces salmonicolor, Candida albicans, and Penicillium notatum). This finding is particularly remarkable since $4 \beta, 10 \alpha$-eudesmane-5 $\beta, 11$-diol (6) is the principal component (34\%) of Cymbopogon distans essential oil ${ }^{16,27}$ also known as lemongrass. The oil of Cymbopogon is used in traditional medicine to treat inflammation, colds and microbial infections. ${ }^{28-29}$ Moreover, the leaves of Cymbopogon distans 
were employed for protecting books from insects and fungi in ancient China. ${ }^{30}$ Our findings could rationalize these observations and applications.

Although many microorganisms have been known as producers of geosmin, reports on naturally occurring geosmin derivatives are extremely scarce. Only dehydrogeosmin was detected by mass spectrometry from the flower scent of Cactaceae. ${ }^{15}$ In this study we isolated several oxygenated geosmin congeners from an endophyte belonging to the genus Streptomyces, which is well-known as geosmin producers. ${ }^{31-32}$ The endophytic actinomycete has a remarkable potential to oxygenate the decalin core of geosmin and closely related terpenoids. These geosmin-modifying oxygenases could find application in water bioremediation. Moreover, we provide a rationale for the antimicrobial potency of the medicinal plant Cymbopogon distans. Overall, the discovery of the geosmin and eudesmane congeners underlines the immense biosynthetic potential of this mangrove endophyte. ${ }^{14}$ Beyond such implications for ecology, our findings may set the basis for biotechnological geosmin remediation.

\section{EXPERIMENTAL SECTION}

General Experimental Procedures. Optical rotations were recorded on a Propol digital automatic polarimeter (Dr. Wolfgang Kernchen $\mathrm{GmbH}$ ). UV spectra were recorded on a Cary 1 Bio UV-visible spectrophotometer (Variant). ECD spectra were obtained on a Jasco J-810-150s spectropolarimeter. IR spectra were recorded on a Bruker FT-IR (IFS 55) spectrometer. NMR spectra were recorded on Bruker Avance III $500 \mathrm{MHz}$ or Avance III $600 \mathrm{MHz}$ spectrometers. Chemical shifts are given on the $\delta$ scale and referenced to $\mathrm{CDCl}_{3}$ at $7.24 \mathrm{ppm}$ for proton and $77.38 \mathrm{ppm}$ for carbon. ESIMS data were obtained on a triple quadrupole mass spectrometer (Quattro; VG Biotech). HRESIMS were recorded on a Finnigan TSQ Quantum Ultra AM Thermo Electron. EI spectra were measured on Thermo Q-Exactive GC. Open column chromatography was performed on silica gel 60 (Merck, 0.04-0.063 mm, 230-400 mesh ASTM) and Sephadex LH-20 (Pharmacia). TLC analysis was performed on silica gel plates (Sil G/UV254, $0.20 \mathrm{~mm}$, Macherey-Nagel). Preparative HPLC was performed on a Waters HPLC system using a Nucleosil 100-5 C18 column $(5 \mu \mathrm{m}, 250 \times 16 \mathrm{~mm})$ with a UV detector. 
Strain Isolation and Taxonomic Classification. JMRC:ST027706 was isolated from the stems of Bruguiera gymnorrhiza. Isolation and taxonomy can be found in the previous report. ${ }^{14}$

Fermentation. Liquid organic medium 79 (dextrose $10 \mathrm{~g}$, bacto peptone $10 \mathrm{~g}$, casamino acids $1 \mathrm{~g}$, yeast extract $\left.2 \mathrm{~g}, \mathrm{NaCl} 6 \mathrm{~g}, \mathrm{H}_{2} \mathrm{O} 1 \mathrm{~L}\right)(2 \times 100 \mathrm{~mL} /$ flask $)$ was inoculated with a suspension of mycelium and spores (about $1 \times 1 \mathrm{~cm}$ ) of Streptomyces sp. JMRC:ST027706 grown on agar slants or agar plates. After incubation for $48 \mathrm{~h}$ on a rotary shaker at $28{ }^{\circ} \mathrm{C}$, the culture was transferred to $3,200 \mathrm{~mL}$ of medium 27 (glucose $20 \mathrm{~g}$, soybean powder $20 \mathrm{~g}, \mathrm{NaCl} 5 \mathrm{~g}, \mathrm{CaCO}_{3} 3 \mathrm{~g}, 1 \mathrm{~L} \mathrm{H}_{2} \mathrm{O}$, eight 1,000 mL scale Erlenmeyer flasks with $400 \mathrm{~mL}$ of medium $27 \mathrm{each}$ ) and incubated at $28{ }^{\circ} \mathrm{C}$ under shaking conditions for $48 \mathrm{~h}$ to yield pre-fermentation culture, which was poured into a $300 \mathrm{~L}$ scale fermenter filled with $200 \mathrm{~L}$ of medium 27 and fermented for 5 days. ${ }^{14}$

Extraction and Isolation. The fermentation broth of Streptomyces sp. JMRC:ST027706 was separated into culture filtrate and mycelia by centrifugation. The fermentation broth was filtered and loaded onto an Amberchrom 161c resin LC column $(200 \times 20 \mathrm{~cm}, 6 \mathrm{~L})$. Elution with a linear gradient of $\mathrm{H}_{2} \mathrm{O} / \mathrm{MeOH}$ (from $30 \%$ to $100 \% \mathrm{v} / \mathrm{v}$, flow rate $0.5 \mathrm{~L} \mathrm{~min}^{-1}$, in $58 \mathrm{~min}$ ) afforded seven fractions (F1-F7). F1-F5 were combined and extracted by EtOAc and evaporated to afford the extract $(8 \mathrm{~g})$. It was first fractionated by silica gel column chromatography with a $\mathrm{CH}_{2} \mathrm{Cl}_{2} / \mathrm{MeOH}$ gradient to yield four fractions, $\mathrm{A}-\mathrm{D}$. Fraction A was first fractionated by a Sephadex LH-20 $\left(\mathrm{CH}_{2} \mathrm{Cl}_{2}, 50 \% \mathrm{MeOH}\right)$ column, and six fractions (A1-A6) were obtained. ${ }^{1}$ Fraction A1 was further separated by a $\mathrm{RP}-\mathrm{C}_{18}$ column $\left(\mathrm{MeOH} / \mathrm{H}_{2} \mathrm{O}\right.$ gradient) to afford 17 fractions, FA1-1 to FA1-23. FA1-10 was separated by HPLC RP-C 18 (MeOH/ $\mathrm{H}_{2} \mathrm{O}$ as gradient) to afford 3 (2.2 mg). FA1-14 was separated by silica gel column chromatography (DCM/MeOH as gradient) to afford $5(2.1 \mathrm{mg})$ and $7(2.1 \mathrm{mg})$. FA1-17 was separated by silica gel column chromatography $\left(\mathrm{CH}_{2} \mathrm{Cl}_{2} / \mathrm{MeOH}\right.$ as 
gradient $)$ to afford $\mathbf{8}(0.6 \mathrm{mg})$. FA1-18 was separated by silica gel column chromatography $\left(\mathrm{CH}_{2} \mathrm{Cl}_{2} / \mathrm{MeOH}\right.$ as gradient) to afford $\mathbf{2}(10.0 \mathrm{mg}), \mathbf{4}(7.3 \mathrm{mg})$, and $\mathbf{6}(1.0 \mathrm{mg})$.

7R-Hydroxygeosmin (2): Colorless solid; $[\alpha]_{D}^{23}-6.2$ (c 0.1, MeOH); IR (film) $v_{\max } 3314,1456,1410,1378$, $1339,1309,1273,1225,1210,1177,1133,1067,1009,988,955,938,905,874,856,833,811,715,670$, $638 \mathrm{~cm}^{-1}$; ${ }^{1} \mathrm{H}$ NMR data, Table $1,{ }^{13} \mathrm{C}$ NMR data, Table 2; EIMS (14 eV): 198, 180, 165, 162, 151, 137, 126, 110, 86, 32; HREIMS (15 eV): m/z 198.1613 (cald for $\mathrm{C}_{12} \mathrm{H}_{22} \mathrm{O}_{2}, 198.1614, \Delta-0.50 \mathrm{ppm}$ ).

3-Oxogeosmin (3): colorless solid; $[\alpha]_{D}^{24}-30.5$ (c 0.07, MeOH); ECD (0.0036 mM, MeOH), $\lambda \max (\Delta \varepsilon)$ 284 (-83.2) nm; IR (film) $v_{\max }$ 3448, 2941, 1686, 1437, 1413, 1372, 1318, 1246, 1171, 1097, 1076, 1060, 1010, 958, 945, 888, 848, 652, $611 \mathrm{~cm}^{-1}$; ${ }^{1} \mathrm{H}$ NMR data, Table $1,{ }^{13} \mathrm{C}$ NMR data, Table 2; EIMS (14 eV): 196, 178, 167, 154, 149, 140, 125, 123, 112, 106, 97, 82, 32. HREIMS (70 eV): m/z 196.14595 (cald for $\left.\mathrm{C}_{12} \mathrm{H}_{20} \mathrm{O}_{2}, 196.14578, \Delta 0.87 \mathrm{ppm}\right)$.

2R-Hydroxy-7-oxogeosmin (4): colorless solid; $[\alpha]_{D}^{24}+8.4$ (c 0.22, MeOH); ECD (0.011 mM, MeOH), $\lambda \max (\Delta \varepsilon) 292$ (4.2) nm; ${ }^{1} \mathrm{H}$ NMR data, Table 1, ${ }^{13} \mathrm{C}$ NMR data, Table 2; EIMS (14 eV): 196, 178, 167, 163, 149, 139, 122, 110, 101, 97, 82, 32; HREIMS (70 eV): $\mathrm{m} / z$ 196.14582 (cald for $\mathrm{C}_{12} \mathrm{H}_{20} \mathrm{O}_{2}, 196.14578$, $\Delta 0.18 \mathrm{ppm})$.

7S,9S-Dihydroxy 5-deoxygeosmin (5): colorless oil; $[\alpha]_{D}^{24}+2.9(c 0.06, \mathrm{MeOH}) ;{ }^{1} \mathrm{H}$ NMR data, Table 1, ${ }^{13} \mathrm{C}$ NMR data, Table 2; EIMS (14 eV): 198, 180, 162, 147, 136, 124, 110, 95, 84, 73, 59, 49, 31; HREIMS (70 eV): $m / z$ 198.1613 (cald for $\mathrm{C}_{12} \mathrm{H}_{22} \mathrm{O}_{2}, 198.1614, \Delta-0.42 \mathrm{ppm}$ ).

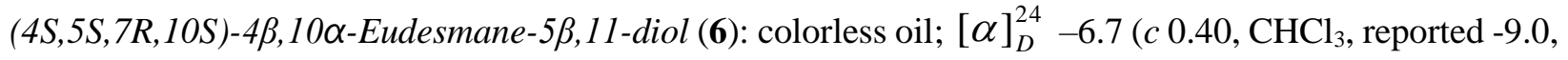
c $0.8, \mathrm{CHCl}_{3}{ }^{17}$ ); IR (film) $v_{\max } 3277,2934,2861,1653,1559,1447,1419,1378,1361,1314,1281,1235$, 1163, 1127, 1103, 1057, 1027, 1005, 956, 924, 899, 873, 831, 777, 667, $612 \mathrm{~cm}^{-1}$; HRESIMS $\mathrm{m} / \mathrm{z}[\mathrm{M}+$ $\mathrm{Na}]^{+} 263.1981$ (cald for $\mathrm{C}_{15} \mathrm{H}_{28} \mathrm{O}_{2} \mathrm{Na}, 263.1982, \Delta 0.04 \mathrm{ppm}$ ).

(1S,5S,6S,7S,10S)-10 $\alpha$-Eudesm-4(15)-ene-1 $\alpha, 6 \alpha$-diol (7): colorless oil; $[\alpha]_{D}^{23}-16.7$ (c $0.21, \mathrm{CHCl}_{3}$, reported -88, $c 0.6, \mathrm{CHCl}_{3}{ }^{21}$ ); IR (film) $v_{\max } 3365,2933,2870,1699,1652,1559,1541,1507,1457,1369$, $1261,1032,986,878,799,756,679,668,630 \mathrm{~cm}^{-1}$.

1(10)E,5E-Germacradiene-2,11-diol (8): colorless solid; $[\alpha]_{D}^{23}-30.4(c 0.10, \mathrm{MeOH}$, reported -42, c 0.52, $\left.\mathrm{MeOH}^{26}\right)$. 
Antimicrobial Assays. Sterile filter paper disks were impregnated with $50 \mu \mathrm{g}$ of the samples using $\mathrm{MeOH}$ as the carrier solvent. The impregnated disks were then placed on agar plates previously inoculated with Bacillus subtilis ATCC 6633, Mycobacterium vaccae IMET 10670, Pseudomonas aeruginosa K799/61, Pseudomonas aeruginosa BG137 B7, Staphylococcus aureus SG511, Staphylococcus aureus 134/94 R9 (methicillin-resistant MRSA), Enterococcus faecalis 1528 R10 (vancomycin-resistant VRE), Escherichia coli SG458, Sporobolomyces salmonicolor SBUG 549, Candida albicans and Penicillium notatum JP36. Chloramphenicol $(5 \mu \mathrm{g})$ and amphotericin $(10 \mu \mathrm{g})$ were used as positive controls against bacteria and fungi, respectively. $\mathrm{MeOH}$ was used as a negative control. After the plates were incubated at $37{ }^{\circ} \mathrm{C}$ for $24 \mathrm{~h}$, antimicrobial activity was recorded as clear zones (in $\mathrm{mm}$ ) of inhibition surrounding the disk. The test sample was considered active when the zone of inhibition was greater than $7 \mathrm{~mm} .{ }^{14}$

\section{ASSOCIATED CONTENT}

\section{Supporting Information}

NMR spectra of compounds 2-7. The Supporting Information is available free of charge on the ACS Publications website at DOI:

\section{AUTHOR INFORMATION}

\section{Corresponding Author}

* Tel: (+) 45-50333791. E-mail: lidi@dtu.dk

\section{Notes}

The authors declare no competing financial interest.

ACKNOWLEDGMENTS. We thank Dr. N. Ueberschaar, A. Perner, and F. Rhein for MS and NMR measurements, respectively, H. Heinecke, and U. Valentin for sample preparation and HPLC, C. Heiden 
and M. Steinacker for fermentation and downstream processing. Financial support by the BMBF (Intercommunicate) is gratefully acknowledged. The study was co-financed by the state of Thuringia (2015 FGI 0021) with means of the EU in the framework of the EFRE program.

\section{REFERENCES}

1. Gerber, N. N.; Lechevalier, H. A. Appl. Environ. Microbiol. 1977, 34, 857-858.

2. Melo, N.; Wolff, G. H.; Costa-da-Silva, A. L.; Arribas, R.; Triana, M. F.; Gugger, M.; Riffell, J. A.; DeGennaro, M.; Stensmyr, M. C. Curr. Biol. 2020, 30, 127-134.

3. Hopwood, D. A. Streptomyces in nature and medicine: the antibiotic makers. New York Oxford University Press, Inc 2007.

4. Stensmyr, M. C.; Dweck H. K. M.; Farhan, A.; Ibba, I.; Strutz, A.; Mukunda, L.; Linz, J.; Grabe,V.; Steck, K.; Lavista-Llanos, S.; Wicher, D.; Sachse, S.; Knaden, M.; Becher, P. G.; Seki, Y.; Hansson, B. S. Cell 2012, 151, 1345-1357.

5. Ömür-Özbek, P.; Little, J. C.; Dietrich, A. M. Water Sci. Technol. 2007, 55, 249-256.

6. La Guerche, S.; Dauphin, B.; Pons, M.; Blancard, D.; Darriet, P. J. Arg. Food Chem. 2006, 54, 91939200.

7. Mochida, K. Y. O. Biocontrol Sci. 2009, 14, 35-38.

8. Jüttner, F.; Watson, S. B. Appl. Environ. Microbiol. 2007, 73, 4395-4406.

9. Ma, L.; Wang, C.; Li, H.; Peng, F.; Yang, Z. Chemosphere 2018, 211, 1166-1175.

10. Beniwal, D.; Taylor-Edmonds, L.; Armour, J.; Andrews, R. C. Chemosphere 2018, 212, 272-281.

11. Ho, L.; Sawade, E.; Newcombe, G. Water Res. 2012, 46, 1536-1548.

12. Zamyadi, A.; Henderson, R.; Stuetz, R.; Hofmann, R.; Ho, L.; Newcombe, G. Water Res. 2015, 83, $171-183$.

13. Eaton, R. W.; Sandusky, P. Biodegradation 2010, 21, 71-79.

14. Ding, L.; Goerls, H.; Dornblut, K.; Lin, W.; Maier, A.; Fiebig, H. H.; Hertweck, C. J. Nat. Prod. 2015, $78,2963-2967$. 
15. Kaiser, R.; Nussbaumer, C. Helv. Chim. Acta 1990, 73, 133-139.

16. Ayer, W. A.; Browne, L. M.; Fung, S.; Stothers, J. B. Org. Magn. Reson. 1978, 11, 73-80.

17. Mathela, C. S.; Melkani, A. B.; Pant, A.; Dev, V.; Nelson, T. E.; Hope, H.; Bottini, A. T. Phytochemistry 1989, 28, 936-938.

18. Ding, N.; Han, L.; Jiang, Y.; Li, G.; Liu, J.; Mu, Y.; Huang, X. Magn. Reson. Chem. 2018, 56, 352-359.

19. Song, J. T.; Han, Y.; Wang, X. L.; Shen, T.; Lou, H. X.; Wang, X. N. Fitoterapia 2015, 107, 54-59.

20. Soares, L. R.; Silva, A. C. d. Q. e.; Freire, T. V.; Garcez, F. R.; Garcez, W. S. Quim. Nova 2012, 35, 323-326.

21. Sun, Z.; Chen, B.; Zhang, S.; Hu, C. J. Nat. Prod. 2004, 67, 1975-1979.

22. Jiang, H. X.; Li, Y.; Pan, J.; Gao, K. Helv. Chim. Acta. 2006, 89, 558 - 566.

23. Zhang, H. J, Tan, G. T., Santarsiero, B. D., Mesecar, A. D., Hung, N. V.; Cuong, N. M.; Doel Soejarto, D, Pezzuto, J. M.; Fong, H. H. J. Nat. Prod. 2003, 66, 609-615.

24. Kuwana, D.; Nagatomo, M.; Inoue, M. Org. Lett. 2019, 21, 7619-7623.

25. Gowrisankar, P.; Céline, B.; Peter, K. E. ChemComm. 2012, 48, 11241-11243.

26. Guan, S.; Grabley, S.; Groth, I.; Lin, W.; Christner, A.; Guo, D.; Sattler, I. Magn. Reson. Chem. 2005, $43,1028-1031$.

27. Beauchamp, P. S.; Dev, V.; Docter, D. R.; Ehsani, R.; Vita, G.; Melkani, A. B.; Mathela, C. S.; Bottini, A. T. J. Essent. Oil Res. 1996, 8, 117-121.

28. Boukhatem, M. N.; Ferhat, M. A.; Kameli, A.; Saidi, F.; Kebir, H. T. Libyan J. Med. 2014, 9, 25431.

29. Khan, M. S.; Ahmad, I. J. Ethnopharmacol. 2012, 140, 416-423.

30. Zhang, J. S.; Zhao, N. N.; Liu, Q. Z.; Liu, Z. L.; Du, S. S.; Zhou, L.; Deng, Z. W. J. Agric. Food Chem. 2011, 59, 9910-9915.

31. Gerber, N. N.; Lechevalier, H. A.. Appl. Microbiol. 1965, 13, 935-938.

32. Pollak, F. C.; Berger, R. G. Appl. Environ. Microbiol. 1996, 62, 1295-1299. 


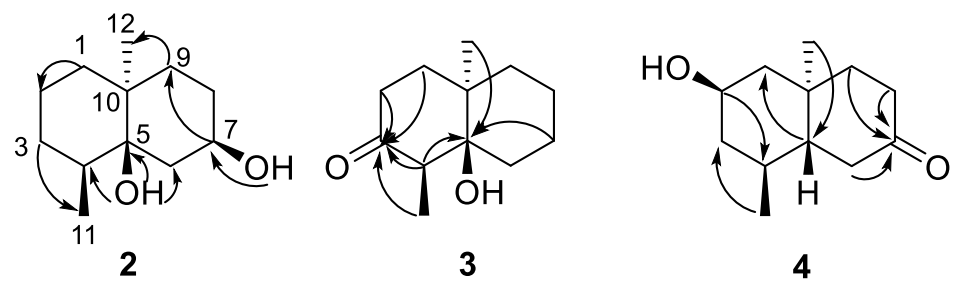

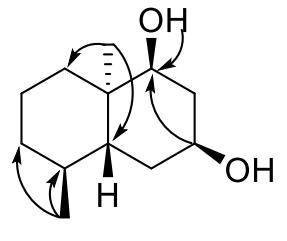

5

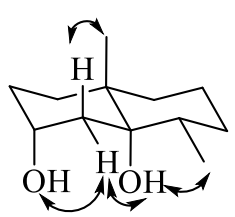

2

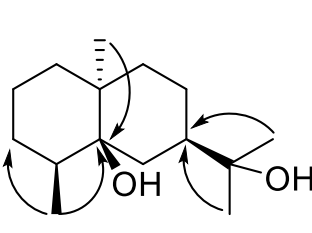

6

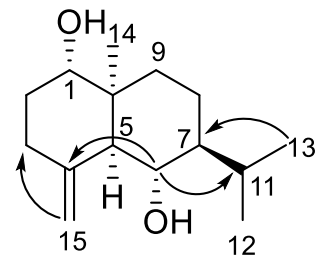

7

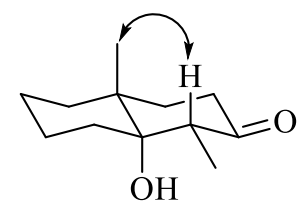

3

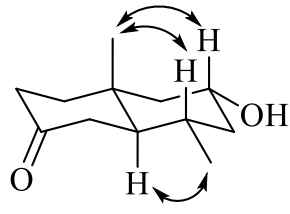

4

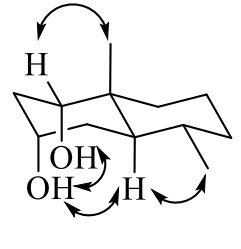

5

Figure 1. Selected HMBC (single arrows) and key NOESY (double arrows) correlations of 2-5. 
Table 1. ${ }^{1} \mathrm{H}$ NMR Data for $\mathbf{2 - 5}\left(\mathrm{CDCl}_{3}, 600 \mathrm{MHz}\right.$ for $\mathbf{2}$ and $\mathbf{5} ; 500 \mathrm{MHz}$ for 3 and $\left.\mathbf{4}\right)$

\begin{tabular}{|c|c|c|c|c|}
\hline \multirow[b]{2}{*}{ Position } & \multicolumn{4}{|c|}{${ }^{1} \mathrm{H}$ NMR $\delta(J$ in $\mathrm{Hz})$} \\
\hline & 2 & 3 & 4 & 5 \\
\hline 1 & $1.62, \mathrm{~m}, 1.43, \mathrm{~m}$ & \multicolumn{2}{|c|}{$\begin{array}{l}2.03, \mathrm{td}(13.2,5.4), 1.75, \mathrm{~m}, 1.30, \mathrm{~m} \\
1.38, \mathrm{~m}\end{array}$} & $1.77, \mathrm{~m}, 1.10, \mathrm{~m}$ \\
\hline 2 & $0.98, \mathrm{~m}$ & \multicolumn{2}{|c|}{$\begin{array}{l}2.47, \text { ddd }(15.1,4.18, \mathrm{~m} \\
13.2,7.2), 2.33, \mathrm{ddd} \\
(15.1,5.4,1.8)\end{array}$} & $1.57, \mathrm{~m}$ \\
\hline 3 & $1.35, \mathrm{~m}$ & - & $1.85, \mathrm{~m}, 1.25, \mathrm{~m}$ & $1.66, \mathrm{~m}, 0.97, \mathrm{~m}$ \\
\hline 4 & $1.62, \mathrm{~m}$ & 2.57, q (6.7) & $1.82, \mathrm{~m}$ & $1.35, \mathrm{~m}$ \\
\hline 5 & - & - & $1.15, \mathrm{~m}$ & $1.52, \mathrm{~m}$ \\
\hline $5-\mathrm{OH}$ & $3.03, \mathrm{~s}$ & - & - & - \\
\hline 6 & \multicolumn{2}{|c|}{$\begin{array}{l}\text { 1.87, } \mathrm{m} 1.48, \mathrm{dd}(14.8,1.57, \mathrm{~m} \\
3.5)\end{array}$} & $2.48, \mathrm{~m}, 2.27, \mathrm{~m}$ & $1.91, \mathrm{~m}, 1.30, \mathrm{~m}$ \\
\hline 7 & 4.08, brs & $1.57, \mathrm{~m}$ & - & $4.13, \mathrm{~m}$ \\
\hline 7-OH & $3.55, \mathrm{~d}(5.6)$ & - & - & $2.91, \mathrm{~d}(6.7)$ \\
\hline 8 & $1.83, \mathrm{~m}, 1.67, \mathrm{~m}$ & $1.51, \mathrm{~m}$ & $\begin{array}{l}2.45, \mathrm{~m}, 2.08, \mathrm{t} \\
(14.4,0.8)\end{array}$ & $\begin{array}{l}\operatorname{td} 1.93, \mathrm{dd}(5.0,2.7), 1.91 \\
\quad \mathrm{t}(3.2)\end{array}$ \\
\hline 9 & \multicolumn{2}{|c|}{$\begin{array}{l}\text { 1.93, td }(13.6,3.9), 0.91,1.62, \mathrm{~m}, 1.21, \mathrm{~m} \\
\text { ddd }(13.6,4.4,2.6)\end{array}$} & \multicolumn{2}{|c|}{$\begin{array}{l}\text { 1.69, ddd }(13.3,6.8,3.31, \mathrm{~m} \\
1.9), 1.39, \operatorname{td}(13.3, \\
5.4)\end{array}$} \\
\hline $9-\mathrm{OH}$ & - & - & - & $2.62, \mathrm{~d}(5.3)$ \\
\hline 10 & - & - & - & - \\
\hline 11 & $0.80, \mathrm{~d}(6.8)$ & $0.95, \mathrm{~d}(6.8)$ & $0.82, \mathrm{~d}(6.5)$ & $0.83, \mathrm{~d}(6.4)$ \\
\hline 12 & $0.98, \mathrm{~s}$ & $1.24, \mathrm{~s}$ & $1.27, \mathrm{~s}$ & $0.79, \mathrm{~s}$ \\
\hline
\end{tabular}


Table 2. ${ }^{13} \mathrm{C}$ NMR Data for $\mathbf{2}-\mathbf{5}\left(\mathrm{CDCl}_{3}, 150 \mathrm{MHz}\right.$ for $\mathbf{2}$ and $\mathbf{5} ; 125 \mathrm{MHz}$ for $\mathbf{3}$ and 4)

\begin{tabular}{|c|c|c|c|c|c|}
\hline & \multirow[b]{2}{*}{ Position } & \multicolumn{4}{|c|}{${ }^{13} \mathrm{C}$ NMR, type } \\
\hline & & 2 & 3 & 4 & 5 \\
\hline 1 & & $20.6, \mathrm{CH}_{2}$ & $35.5, \mathrm{CH}_{2}$ & $46.3, \mathrm{CH}_{2}$ & $34.7, \mathrm{CH}_{2}$ \\
\hline 2 & & 34.6, $\mathrm{CH}_{2}$ & $37.9, \mathrm{CH}_{2}$ & $67.4, \mathrm{CH}$ & 21.4, $\mathrm{CH}_{2}$ \\
\hline 3 & & 29.7, $\mathrm{CH}_{2}$ & $212.0, \mathrm{C}$ & $42.8, \mathrm{CH}_{2}$ & $36.4, \mathrm{CH}_{2}$ \\
\hline 4 & & $34.0, \mathrm{CH}$ & $49.5, \mathrm{CH}$ & $27.5, \mathrm{CH}$ & $31.2, \mathrm{CH}$ \\
\hline 5 & & $76.4, \mathrm{C}$ & 78.7, C & $50.8, \mathrm{CH}$ & $37.3, \mathrm{CH}$ \\
\hline 6 & & $34.8, \mathrm{CH}_{2}$ & $30.7, \mathrm{CH}_{2}$ & 41.2, $\mathrm{CH}_{2}$ & $32.3, \mathrm{CH}_{2}$ \\
\hline 7 & & $68.0, \mathrm{CH}$ & $20.5, \mathrm{CH}_{2}$ & 212.1, C & $68.3, \mathrm{CH}$ \\
\hline 8 & & 28.7, $\mathrm{CH}_{2}$ & $20.3, \mathrm{CH}_{2}$ & $37.5, \mathrm{CH}_{2}$ & $33.3, \mathrm{CH}_{2}$ \\
\hline 9 & & $30.3, \mathrm{CH}_{2}$ & $35.1, \mathrm{CH}_{2}$ & $41.0, \mathrm{CH}_{2}$ & $76.9, \mathrm{CH}$ \\
\hline 10 & & $37.5, \mathrm{C}$ & $37.3, \mathrm{C}$ & $33.0, \mathrm{C}$ & $38.5, \mathrm{C}$ \\
\hline 11 & & $14.9, \mathrm{CH}_{3}$ & $6.6, \mathrm{CH}_{3}$ & $19.1, \mathrm{CH}_{3}$ & $20.1, \mathrm{CH}_{3}$ \\
\hline 12 & & $20.0, \mathrm{CH}_{3}$ & $20.7, \mathrm{CH}_{3}$ & $18.2, \mathrm{CH}_{3}$ & $16.4, \mathrm{CH}_{3}$ \\
\hline
\end{tabular}


Table 3. Antimicrobial Activities of Compounds 2, 3 and 6 (Agar Diffusion Assay, $50 \mu \mathrm{g} / \mathrm{paper}$ disk).

\begin{tabular}{|c|c|c|c|c|c|c|c|c|c|}
\hline \multirow[b]{2}{*}{ Cpd } & \multicolumn{9}{|c|}{ Test strains } \\
\hline & $\begin{array}{c}\text { B. } \\
\text { subtilis }\end{array}$ & $\begin{array}{c}. \\
\text { aureus }\end{array}$ & $\begin{array}{c}E . \\
\text { coli }\end{array}$ & $\begin{array}{c}P . \\
\text { aeruginosa }\end{array}$ & MRSA & VRE & $\begin{array}{c}\text { M. } \\
\text { vaccae }\end{array}$ & $\begin{array}{c}. \\
\text { salmonicolor }\end{array}$ & $\begin{array}{c}P . \\
\text { notatum }\end{array}$ \\
\hline 2 & 10 & 0 & 10 & 10 & 0 & 0 & 0 & 0 & 0 \\
\hline 3 & 10 & 0 & 0 & 10 & 0 & 10 & 0 & 0 & 0 \\
\hline 6 & 12 & 12 & 10 & 11 & 11 & 11 & 14 & 12 & 12 \\
\hline chloramphenicol & 29 & 17 & 23 & 24 & 0 & 17 & 20 & - & - \\
\hline amphotericin b & - & - & - & - & - & - & 13 & 13 & 17 \\
\hline
\end{tabular}


TOC Graphic

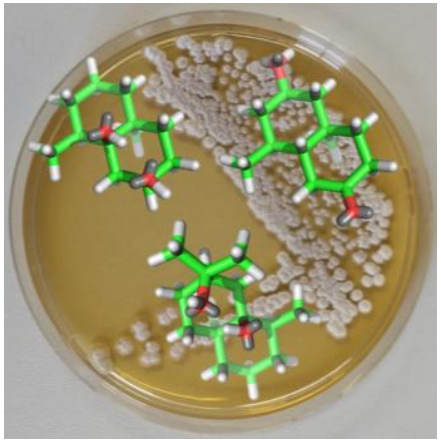

